\title{
SYNTHESIS, SPECTRAL CHARACTERIZATION OF SCHIFF BASE COMPLEXES BASED ON PYRIMIDINE MOIETY WITH MOLECULAR DOCKING WITH BIOMOLECULES
}

\author{
MOHANAMBAL $\mathrm{D}^{1,2 *}$, ARULANTONY $\mathrm{S}^{3}$ \\ ${ }^{1}$ Research and Development Centre, Bharathiar University Coimbatore, Tamil Nadu, India. ${ }^{2}$ Department of Chemistry, Sriram Engineering \\ College, Chennai, Tamil Nadu, India. ${ }^{3}$ Department of Chemistry, Presidency College, Chennai, Tamil Nadu, India. \\ Email: mohanachem2010@gmail.com \\ Received: 21 April 2018, Revised and Accepted: 15 May 2018
}

ABSTRACT

Objective: Aim of this study is to synthesize new bidentate complexes of type $\mathrm{MX}_{2}$. $\mathrm{nH}_{2} \mathrm{O}$ with 4 amino antipyrine and ethyl 4-methyl-2-oxo-6phenylhexahydropyrimidine-5-carboxylate (DHPM) and to characterize their properties, namely elemental analysis, conductivity measurements, and spectral characteristics and to establish the binding between the Schiff base ligands and complexes with human epidermis cancer cells (Hep-2) through molecular docking.

Method: A new bidentate complexes were synthesized by condensation reaction of $\mathrm{MX}_{2} \cdot \mathrm{nH}_{2} \mathrm{O}$ (M = Cu (II), $\mathrm{Zn}$ (II), Co (II)) with 4-aminoantipyrine (A) and DHPM in methanol under atmospheric pressure.

Results: All the compounds have been characterized by elemental analysis, conductance measurements, magnetic moments, and spectroscopy techniques such as ultraviolet-visible, infrared (IR), ${ }^{1} \mathrm{H}$ and ${ }^{13} \mathrm{C}$ nuclear magnetic resonance, and electron spin resonance (ESR). The IR showed that nature of functional group present in the ligand (Lp) acts as neutral bidentate through the azomethane nitrogen atom and carbonyl oxygen moiety and its complexes formation. The ESR spectral data of copper complex provided information about their structure on the basis of Hamiltonian parameters and degree of covalency. The antimicrobial (Escherichia coli, Salmonella typhi, Bacillus subtilis, and aureus) and antifungal (Candida and Aspergillus niger) activities of the complexes were tested against various microorganism by disc diffusion method.

Conclusion: The antimicrobial activity indicates that the metal complexes are more active than the ligand. Molecular docking was used to predict the binding between the Schiff base ligands and complexes with human epidermis cancer cells (Hep-2).

Keywords: Schiff base molecular structure, Nuclear magnetic resonance, Fourier transform infrared, Electron spin resonance study, Molecular docking with biomolecules.

(C) 2018 The Authors. Published by Innovare Academic Sciences Pvt Ltd. This is an open access article under the CC BY license (http://creativecommons. org/licenses/by/4. 0/) DOI: http://dx.doi.org/10.22159/ajpcr.2018.v11i10.26823

\section{INTRODUCTION}

Transition metal (II) ion coordination complexes of well-defined structures and it play an important role in the numerous biological processes that involve electron transfer reaction or the activation of some antitumor activities [1]. Schiff base ligands are significant important stereochemical models in main group and transition metal. It due to their preparative accessibility and structural variety especially of ligands is potentially capable to form stable complexes with metal ions [2]. Schiff bases of 4-aminoantipyrine and its transition metal complexes have various applications [3-5]. Heterocyclic containing dihydropyrimidinone ring is present in a number of pharmacologically and biologically active compounds [6]. Compounds containing benzothiazole derivatives were used as antifungal, anti-inflammatory, anti- HIV, and anticancer activities [7-9]. The numerous biological experiments performed so far suggest that DNA is the primary intracellular target of anticancer drugs because the interaction between small molecules and can induce DNA damages to cause cancer $[10,11]$.

We synthesized and characterized novel Schiff base metal Co (II), $\mathrm{Ni}$ (II), Cu (II), and Zn(II) complexes. In the present study, in silico molecular docking studies of ligand and their metal complex against BCL-2(PDB id: Bcl-xl: 2YXJ) have been carried out using Glide module of Schrodinger 2009. The docking studies which are reported in terms of the docking energy score, which means the lower, the score, the better, and the interaction. The ligand and metal complexes were individually docked with (Laryngeal carcinoma) BCL-2 as the target protein.

\section{MATERIAL AND METHODS}

Benzaldehyde, ethyl acetoacetate, urea, and metal halide salts were purchased from E Merck chemical company and used without further purification; ethanol refers to absolute ethanol unless otherwise specified. Carbon, hydrogen, and nitrogen were estimated using elemental analyzer Carlo ErbaEA1108 analyzer. Molar conductivity measurements were recorded on ELICO-CM-82 $\mathrm{T}$ conductivity Bridge with a cell having cell constant 0.51 and the magnetic moment was carried out using Faraday balance. The IR spectra of the Schiff bases and its complexes were recorded on a Shimadzu- 8400 IR spectrophotometer. The ${ }^{1} \mathrm{H}$ nuclear magnetic resonance (NMR) and ${ }^{13} \mathrm{C}$ NMR spectra of ligands were recorded in dimethyl sulfoxide (DMSO)- $\mathrm{d}^{6}$ on a BRUKER $300 \mathrm{MHz}$ spectrometer at room temperature using TMS as an internal reference. Mass spectra were recorded on a JEOL SX 102/DA-6000 mass spectrometer/data system. The ultraviolet (UV)-visible spectra of the complexes were recorded in high-performance liquid chromatography grade DMSO solvent on a Shimadzu-1800 UV-visible spectrophotometer in the region of 200-1100 $\mathrm{nm}$. The electron spin resonance (ESR) spectrum was recorded on Varian-E-4X-band electron paramagnetic resonance (EPR) spectrometer, and the fieldset is $3000 \mathrm{G}$ at a modulation frequency of $100 \mathrm{kHz}$ under room temperature using TCNE as g marker.

\section{Preparation of Schiff base}

An ethanolic solution of 4-aminoantipyrine $(2.03 \mathrm{~g}, 0.01 \mathrm{~mol}$, and $20 \mathrm{~mL}$ ) was added to the ethanolic solution of ethyl 4-methyl-2oxo-6-phenylhexahydropyrimidine-5-carboxylate $(2.6 \mathrm{~g}, 0.01 \mathrm{~mol}$, and $20 \mathrm{~mL}$ ) with constant stirring at $60^{\circ} \mathrm{C}$ for $4 \mathrm{~h}$. After cooling the solution, the precipitate was separated, filtered, recrystallized 
with ethanol, and dried over anhydrous calcium chloride under vacuum [12] yield $62.9 \%$; m.p. $233^{\circ} \mathrm{C}$, the scheme of preparation is given in Scheme 1.

Synthesis of the [M (4-aminoantipyro-2-oxo-phenyl hexahydropyrimidine-5-carboxylate [APDM] $)_{2} \mathrm{Cl}_{2}$ ] complexes

The hot alcoholic solution of the $\mathrm{M}$ (II) $\mathrm{Cl}_{2} .5 \mathrm{H}_{2} \mathrm{O}$ (0.01 mol [2.65 g]) was slowly added to the hot alcoholic solution of the ligand $(0.02 \mathrm{~mol})$. The resulting mixture was refluxed for $5 \mathrm{~h}$, few drops of very dilute ammonia were added in drops to the reaction. The colored precipitate obtained was separated by filtration, washed with distilled ethanol and ether. The products were dried and stored atmosphere (Scheme 2).

\section{RESULTS AND DISCUSSION}

\section{Physical properties}

The ligand: (2E)-ethyl 2-(2, 5-dihydro-2,3-dimethyl-5-oxo-1phenyl-1H-pyrazol-4-ylimino)-1，2，3， 4-tetrahydro-6-methyl-4phenylpyrimidine-5 caroxylate is the ligand (APDM) is yellow colored solids, amorphous in nature stable at room temperature and insoluble in water, slightly soluble in ethanol and acetone and fairly soluble in hot ethanol, $\mathrm{CH}_{3} \mathrm{Cl}$. The complexes of $\mathrm{Mn}(\mathrm{II}), \mathrm{Co}(\mathrm{II}), \mathrm{Ni}(\mathrm{II}), \mathrm{Cu}(\mathrm{II})$, and $\mathrm{Zn}(\mathrm{II})$, and stable in room temperature. The complexes are fairly soluble in hot ethanol, dimethylformamide, and dimethyl sulfoxide.

\section{Elemental analysis}

The analytical data of the metal complexes of Ligand (APDM) are presented in Table 1. It may be seen from the table that the experimental values are in fair agreement with the calculated ones. The molecular formula of the ligand and their metal complexes has been suggested according to the above-mentioned data together with those obtained from spectral, conductivity, and magnetic susceptibility of metal complexes.

Fourier transform infrared (FT-IR) spectra of ligand and complexes The IR spectra provide valuable information regarding the nature of the functional groups present in the ligand and coordination mode of the metal atom with the ligand. The characteristic IR frequencies of the free ligands and their metal (II) complexes are given in Table 2.

In general, the IR spectra of the free ligand showed a broadband around $3425 \mathrm{~cm}^{-1}$ which could be attributed to $\mathrm{NH}$ stretching vibration of benzimidazole moiety. The position of this band remained at nearly the same frequency in the spectra of the metal complexes suggesting the absence of the $\mathrm{NH}$ group coordination [13]. The stretching frequency of carbonyl group of ligand $v(C=0)$ at $1702 \mathrm{~cm}^{-1}$ is shifted to lower frequency range $1688-1699 \mathrm{~cm}^{-1}$ and is attributed to complexes formation with metal. Similarly, the frequency corresponding to $v(\mathrm{C}=\mathrm{N})$ at $1647 \mathrm{~cm}^{-1}$ shifted range $1587-1635 \mathrm{~cm}^{-1}$ in complexes [14]. The shifting in wave number and their intensities of referenced bands led to predict the coordination behavior. The spectra of metal complexes also show additional bands in between $617-642 \mathrm{~cm}^{-1}, 480-583 \mathrm{~cm}^{-1}$, and 317-326 $\mathrm{cm}^{-1}$ which are probably due to the formation of $v(\mathrm{M}-0)$, $v(\mathrm{M}-\mathrm{N})$, and $v(\mathrm{M}-\mathrm{Cl})$ bond, respectively $[15,16]$. Thus, the IR spectral results provided strong evidence for the complexation of Schiff base with metal ions through bidentate mode by azomethine and carboxyl oxygen groups.

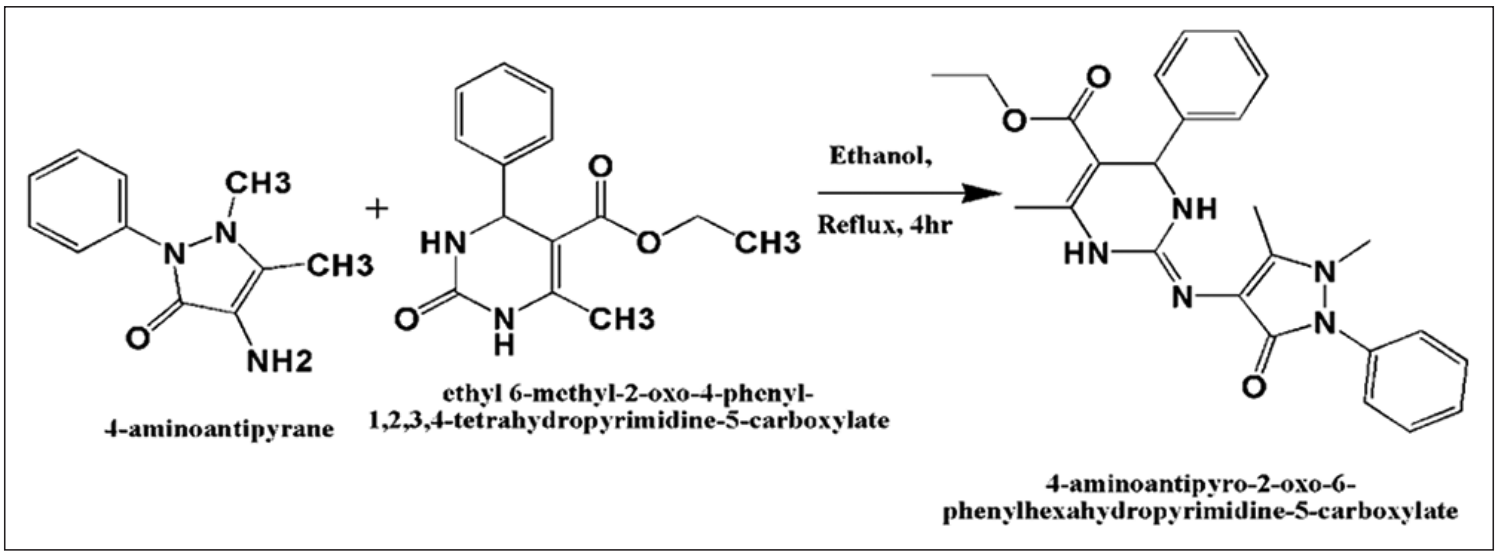

Scheme 1: Synthesis of Schiff base of 4-aminoantipyrine-2-oxo-6-phenyl hexahydropyrimidine-5-carboxylate

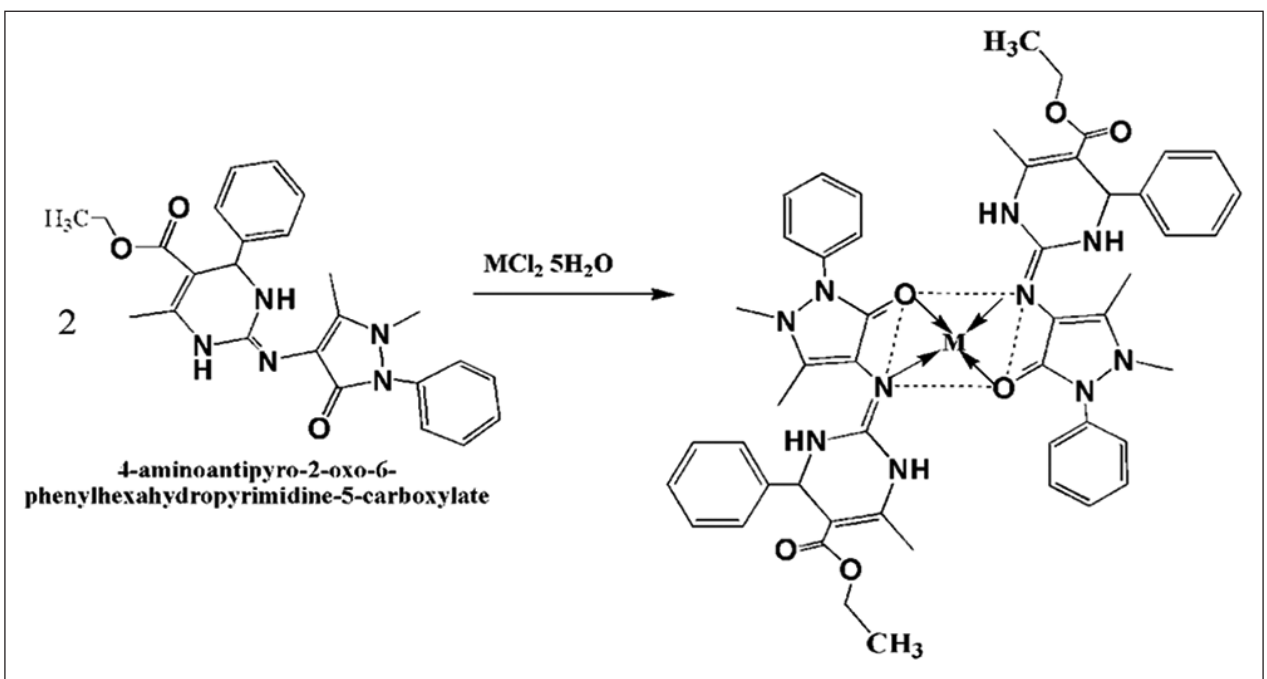

Scheme 2: Synthesis of metal (II) Schiff base complexes of (4-aminoantipyrine-2-oxo-6-phenyl hexahydropyrimidine-5-carboxylate) 
Table 1: Physical and analytical data of the (APDM) ligand and its metal (II) complexes

\begin{tabular}{|c|c|c|c|c|c|c|c|}
\hline \multirow[t]{2}{*}{ Compound } & \multirow[t]{2}{*}{ Mol. formula } & \multirow[t]{2}{*}{$\mathbf{m} \cdot \mathbf{p}\left({ }^{\circ} \mathrm{C}\right)$} & \multicolumn{4}{|c|}{ Found (Calc).(\%) } & \multirow{2}{*}{$\begin{array}{l}\text { Molar conductance } \\
\mathrm{Ohm}^{-1} \mathrm{~cm}^{2} \\
\mathrm{~mol}^{-1} \times 10^{-3}\end{array}$} \\
\hline & & & $\mathrm{C}$ & $\mathbf{H}$ & $\mathbf{N}$ & $\mathbf{M}$ & \\
\hline \multirow{6}{*}{$\begin{array}{l}\text { APDM } \\
\text { Mn } \\
(\mathrm{APDM})_{2} \\
\mathrm{Co} \\
(\mathrm{APDM})_{2} \\
\mathrm{Ni} \\
\left(\mathrm{APDM}{ }_{2}\right. \\
\mathrm{Cu} \\
(\mathrm{APDM})_{2} \\
\mathrm{Zn} \\
(\mathrm{APDM})_{2}\end{array}$} & $\mathrm{C}_{25} \mathrm{H}_{27} \mathrm{~N}_{5} \mathrm{O}_{3}$ & 233 & $66.89(67.40)$ & $6.08(6.11)$ & $15.89(15.72)$ & - & - \\
\hline & $\operatorname{Mn}\left(\mathrm{C}_{25} \mathrm{H}_{27} \mathrm{~N}_{5} \mathrm{O}_{3}\right)_{2}$ & 252 & 59.06 & 5.35 & 13.77 & 5.40 & 3 \\
\hline & Co $\left(\mathrm{C}_{25} \mathrm{H}_{27} \mathrm{~N}_{5} \mathrm{O}_{3}\right)_{2}$ & 260 & $\begin{array}{l}58.66 \\
(58.83)\end{array}$ & $\begin{array}{l}5.48 \\
(5.33)\end{array}$ & $\begin{array}{l}13.87 \\
(13.72)\end{array}$ & $\begin{array}{l}5.07 \\
(5.77)\end{array}$ & 2.4 \\
\hline & $\mathrm{Ni}\left(\mathrm{C}_{25} \mathrm{H}_{27} \mathrm{~N}_{5} \mathrm{O}_{3}\right)_{2}$ & 214 & $\begin{array}{l}59.01 \\
(58.84)\end{array}$ & $\begin{array}{l}5.32 \\
(5.33)\end{array}$ & $\begin{array}{l}13.43 \\
(13.72)\end{array}$ & $\begin{array}{l}5.45 \\
(5.75)\end{array}$ & 1.35 \\
\hline & $\mathrm{Cu}\left(\mathrm{C}_{25} \mathrm{H}_{27} \mathrm{~N}_{5} \mathrm{O}_{3}\right)_{2}$ & 265 & $\begin{array}{l}58.33 \\
(58.56)\end{array}$ & $\begin{array}{l}5.02 \\
(5.31)\end{array}$ & $\begin{array}{l}13.98 \\
(13.66)\end{array}$ & $\begin{array}{l}5.97 \\
(6.20)\end{array}$ & 2.4 \\
\hline & $\mathrm{Zn}\left(\mathrm{C}_{25} \mathrm{H}_{27} \mathrm{~N}_{5} \mathrm{O}_{3}\right)_{2}$ & 241 & $\begin{array}{l}58.33 \\
(58.46)\end{array}$ & $\begin{array}{l}5.48 \\
(5.30)\end{array}$ & $\begin{array}{l}13.60 \\
(13.63)\end{array}$ & $\begin{array}{l}6.44 \\
(6.37)\end{array}$ & 1.8 \\
\hline
\end{tabular}

APDM: 4-aminoantipyrine-2-oxo-6-phenyl hexahydropyrimidine-5-carboxylate

Table 2: IR spectral data of the (4-aminoantipyrine-2-oxo-6-phenyl hexahydropyrimidine-5-carboxylate) ligand and its complexes

\begin{tabular}{lllllll}
\hline Compound & $v_{\mathbf{C}=\mathbf{0}}$ & $v_{\mathbf{C}=\mathbf{N}}$ & $v_{\mathbf{M}-\mathbf{0}}$ & $v_{\mathbf{M}-\mathbf{N}}$ & $\mathrm{N}_{\mathbf{C}-\mathbf{H}}$ & $v_{\mathbf{O H}}$ \\
\hline $\mathrm{L}_{1}$ & 1702 & 1647 & - & - & 3500 & 3300 \\
{$\left[\mathrm{MnL}_{2} \mathrm{Cl}_{2}\right]$} & 1687 & 1610 & 608 & 544 & 3500 & 3200 \\
{$\left[\mathrm{CoL}_{2}\right] \mathrm{Cl}_{2}$} & 1683 & 1602 & 610 & 546 & 3400 & 3100 \\
{$\left[\mathrm{NiL}_{2}\right] \mathrm{Cl}_{2}$} & 1680 & 1599 & 613 & 530 & 3420 & 3120 \\
{$\left[\mathrm{CuL}_{2}\right] \mathrm{Cl}_{2}$} & 1677 & 1594 & 614 & 557 & 3380 & 3200 \\
{$\left[\mathrm{ZnL}_{2}\right] \mathrm{Cl}_{2}$} & 1699 & 1615 & 602 & 528 & - & - \\
\hline
\end{tabular}

${ }^{1} \mathrm{H}$ NMR and ${ }^{13} \mathrm{C}$-NMR of 3-aminopropyldimethylethoxysilane (APDM) ligand and its complexes studies

The NMR spectra of free ligands were determined in $\mathrm{CDCl}_{3}$. The ${ }^{1} \mathrm{H} \mathrm{NMR}$ spectral data are showed various chemical shift values. All the ligands of protons were found to be in the expected regions. The ${ }^{1} \mathrm{H}$ NMR spectra show a multiplet at 6.10-7.52 ppm (m, 10H, Ar) due to phenyl group, $-\mathrm{N}$ $\mathrm{CH}_{3}$ at $2.3 \mathrm{ppm}(\mathrm{s}, 3 \mathrm{H}),=\mathrm{C}-\mathrm{CH}_{3}$ at $\delta 1.72 \mathrm{ppm}\left(\mathrm{s}, 6 \mathrm{H}, 2=\mathrm{C}^{-\mathrm{CH}_{3}}\right), \mathrm{CH}_{3}-\mathrm{CH}_{2}$ at $\delta$ 1.137-1.17 ppm (t, 3H), $\mathrm{CH}$ at 5.386-5.497 ppm (d, $1 \mathrm{H}, \mathrm{CH}), \mathrm{CH}_{3 .}$ $\mathrm{CH}_{2}$ at 4.05-4.07 ppm (q, 2H), and $\mathrm{NH}$ at $8.31 \mathrm{ppm}(\mathrm{s}, \mathrm{br}, 1 \mathrm{H})$; there was a prominent peak that appeared in all spectra at $77 \mathrm{ppm}$, this resulted from the solvent $\mathrm{CDCl}_{3}$ used in analysis. There were a total of 15 peaks which confirmed the structure of the ligand. The ${ }^{1} \mathrm{H}$ NMR spectra are conformed complex with metal ligands. In the ${ }^{13} \mathrm{C}$ NMR spectra of the Schiff bases APDM ligand and the signals appeared in region $\delta 109.6-$ $146.7 \mathrm{ppm}$ are assigned to aromatic carbons. The pyrazoline ring carbon appeared at $\delta 146.0-143 \mathrm{ppm}$. The signals due to methyl carbon were observed around 22-19 ppm. The signals appear for $\mathrm{C}=\mathrm{N}$ and carbon of $\mathrm{C}=0$ at $\delta 165.0-162.2$ and $\delta 153.2-169.7 \mathrm{ppm}$, respectively. Thus, NMR information further supports the apprehension of IR results.

\section{Electronic spectra APDM ligand and its complexes studies}

The variety of colors among transition metal complexes arises from the electronic transition between the energy levels depends on the factors such as geometry of the complex, the nature of the ligands present and the oxidation state of the central metal atom. In complexes, these transitions are frequently referred to as $d-d$ transitions because they involve the molecular orbitals that are mainly metal d orbital [17]. The electronic spectra of complexes can provide valuable information relating to bonding and structure [18]. Obviously, the colors produced are related to the magnitude of the spacing between the energy levels.

Since a charge transfer transition originates from the redox character of the metal ion and the ligand, it is of two distinct types, namely ligand to metal and metal to ligand [19]. The electronic spectra of ligand and its complexes were recorded in ethanol in the range $800-200 \mathrm{~nm}$. The absorption regions, assignments and the geometry of the complexes are given in Table 3. In the electronic spectrum of the ligand, there are two absorption bands around 286-301 nm assigned to $n-\pi^{*}$ and $\pi-\pi^{*}$ transitions. These transitions are also found in the spectra of the complexes, but they are shifted toward longer wavelength from ligand to complex, indicating coordination of ligand to metals through the azomethine moiety.

The electronic spectrum showed at $524 \mathrm{~nm}$ is assigned to ${ }^{2} \mathrm{~B}_{1 \mathrm{~g}} \rightarrow^{2} \mathrm{~A}_{1 \mathrm{~g}}$ transition. These values suggested a square planar geometry. In the Co (II) complex, the band at $612 \mathrm{~nm}$ and $426 \mathrm{~nm}$ is attributed to d-d electronic transition type ${ }^{2} \mathrm{~A}_{1 \mathrm{~g}} \rightarrow{ }^{2} \mathrm{~B}_{1 g^{\prime}}{ }^{2} \mathrm{~A}_{1 \mathrm{~g}} \rightarrow{ }^{2} \mathrm{E}_{g^{\prime}}$ suggesting square planar about Co ions [20]. The spectrum of Mn(II) complex displays a broad shoulder such as absorption band near $560 \mathrm{~nm}$ and a very weak shoulder around $383 \mathrm{~nm}$ in ethanol. The high energy band may be due to charge-transfer whereas the band at $560 \mathrm{~nm}$ may be assigned to d-d transition from the partially spin-paired ground term ${ }^{4} \mathrm{~A}_{1 \mathrm{~g}}\left(\mathrm{~b}_{2 \mathrm{~g}}^{2} \mathrm{e}_{\mathrm{g}}^{2} \mathrm{a}_{1 \mathrm{~g}}^{1}\right)$ to the $\mathrm{b} 1 \mathrm{~g}(\mathrm{~d} x \mathrm{x})$ orbital, i.e., $\left(\mathrm{b}^{2}{ }_{2 \mathrm{~g}} \mathrm{e}^{2} \mathrm{a}^{1}{ }_{1 \mathrm{~g}}\right) \rightarrow\left(\mathrm{b}^{2}{ }_{2 \mathrm{~g}} \mathrm{e}_{\mathrm{g}}^{1} \mathrm{a}^{1}{ }_{1 \mathrm{~g}} \mathrm{~b}^{1}{ }_{1 \mathrm{~g})}\right.$. This may be consistent with a square-planar environment for Mn (II) complex.

The observed diamagnetism and broad medium band at $426 \mathrm{~nm}$ in the spectrum of $\left(\mathrm{NiL}_{2}\right) \mathrm{Cl}_{2}$ were attributed to (d-d) electronic transition type ${ }^{1} \mathrm{~B}_{1 \mathrm{~g}} \leftarrow \mathrm{H}_{1 \mathrm{~g}}$, suggesting a square planar structure [21]. The electronic spectra of $\mathrm{Zn}$ (II) complexes give only charge transfer in the range $25000-3421 \mathrm{~cm}^{-1}$ due to the $\left(\mathrm{d}^{10}\right)$ configuration the metal ions, suggesting tetrahedral structure. On the basis of the above observations and from the diamagnetic nature, UV-visible data, the structure for the complexes could be proposed as follows: A square planar geometry for $\mathrm{Ni}$ (II), Mn(II), Co(II), and a tetrahedral geometry for Zn (II) complexes.

\section{ESI mass spectra of APDM ligand and its complexes studies}

ESI mass spectra provide a vital clue for elucidating the structure of complexes. It showed a molecular ion peak $\left(\mathrm{M}^{+}\right) \mathrm{m} / \mathrm{z}$ at 445.07 which was equivalent to its molecular weight. The base peak at $\mathrm{m} / \mathrm{z}=187$ was due to 4-aminoantipyrine $\left(\mathrm{C}_{11} \mathrm{H}_{11} \mathrm{~N}_{2} \mathrm{O}\right)^{+}$ion. Another intense peak at $\mathrm{m} / \mathrm{z}=274$ was due to $\left(\mathrm{C}_{14} \mathrm{H}_{16} \mathrm{~N}_{3} \mathrm{O}_{3}\right)^{+}$ion. The different competitive fragmentation pathways of ligand gave the peaks at different mass numbers at 257, 185, 173,171, 147, 132, 82, 77, and 56 due to $\left(\mathrm{C}_{14} \mathrm{H}_{15} \mathrm{~N}_{3} \mathrm{O}_{2}\right)^{+},\left(\mathrm{C}_{11} \mathrm{H}_{11} \mathrm{~N}_{3}\right)^{+},\left(\mathrm{C}_{10} \mathrm{H}_{9} \mathrm{~N}_{2} \mathrm{O}\right)^{+},\left(\mathrm{C}_{10} \mathrm{H}_{9} \mathrm{~N}_{3}\right)^{+},\left(\mathrm{C}_{8} \mathrm{H}_{9} \mathrm{~N}_{3}\right)^{+},\left(\mathrm{C}_{8} \mathrm{H}_{8} \mathrm{~N}_{2}\right)^{+}$, $\left(\mathrm{C}_{3} \mathrm{H}_{2} \mathrm{~N}_{2} \mathrm{O}\right)^{+},\left(\mathrm{C}_{6} \mathrm{H}_{5}\right)^{+}$, and $\left(\mathrm{C}_{2} \mathrm{H}_{4} \mathrm{~N}_{2}\right)^{+}$ions, respectively. The intensity of these peaks reflected the stability and abundance of the ions [22]. The spectrum of $\left(\mathrm{MnL}_{2}\right) \mathrm{Cl}_{2},\left(\mathrm{CoL}_{2}\right) \mathrm{Cl}_{2}$, and $\left(\mathrm{CuL}_{2}\right) \mathrm{Cl}_{2}$ showed a molecular ion peak $\left(\mathrm{M}^{+}\right)$at $\mathrm{m} / \mathrm{z} 1048.78,1052.76$, and 1057.30 , respectively, that was corresponding to their molecular weight. All these fragments lead to the formation of the species $\left(\mathrm{ML}_{2}\right)^{+}$which further undergo demetallation to yield the species (L) ${ }^{+}$gave the fragment ion peak; at $\mathrm{m} / \mathrm{z} 461$. Thus, the data obtained from mass spectra confirmed the stoichiometry of metal (1:2) ratio and in good agreement with the micro-analytical data. The discussion suggests that the mass spectra data are correlated with elemental analyses and from the molar conductance data are found that all the complexes are non-electrolytes. 
Table 3: Electronic spectral data of the Schiff bases and their metal complexes

\begin{tabular}{|c|c|c|c|c|}
\hline Compound & Absorption maxima (nm) & Band assignment & Magnetic moment B.M & Geometry \\
\hline \multirow[t]{2}{*}{ Ligand } & 242 & $\pi-\pi^{*}$ & - & - \\
\hline & 301 & $n-\pi^{*}$ & & \\
\hline \multirow{4}{*}[\mathrm{CuL}_{2}]{} & 296 & INCT & Diamagnetic & Square Planar \\
\hline & 325 & INCT & & \\
\hline & 426 & ${ }^{1} A_{2 g} \leftarrow{ }^{1} A_{1 g}$ & & \\
\hline & 556 & ${ }^{1} \mathrm{~B}_{1 \mathrm{~g}} \leftarrow{ }^{1} \mathrm{~A}_{1 \mathrm{~g}}$ & & \\
\hline \multirow[t]{2}{*}[\mathrm{MnL}_{2}]{} & 383 & $\left(b^{2}{ }_{2 g} e^{2} a^{1}{ }_{1 g}\right) \rightarrow\left(b^{2}{ }_{2 g} e^{1} a^{1}{ }_{1 g} b^{1}{ }_{1 g}\right)$ & Diamagnetic & Tetrahedral \\
\hline & 560 & & & \\
\hline \multirow[t]{4}{*}[\mathrm{CoL}_{2}]{} & 293 & INCT & Diamagnetic & Tetrahedral \\
\hline & 324 & INCT & & \\
\hline & 426 & ${ }^{2} \mathrm{~A}_{1 \mathrm{~g}} \rightarrow{ }^{2} \mathrm{~B}_{1 \mathrm{~g}}{ }^{2} \mathrm{~A}_{1 \mathrm{~g}} \rightarrow{ }^{2} \mathrm{E}_{\mathrm{g}}$ & & \\
\hline & 612 & & & \\
\hline \multirow[t]{3}{*}[\mathrm{NiL}_{2}]{} & 296 & INCT & Diamagnetic & Square Planar \\
\hline & 325 & INCT & & \\
\hline & 426 & ${ }^{1} A_{2 g} \leftarrow{ }^{1} A_{1 g}$ & & \\
\hline
\end{tabular}

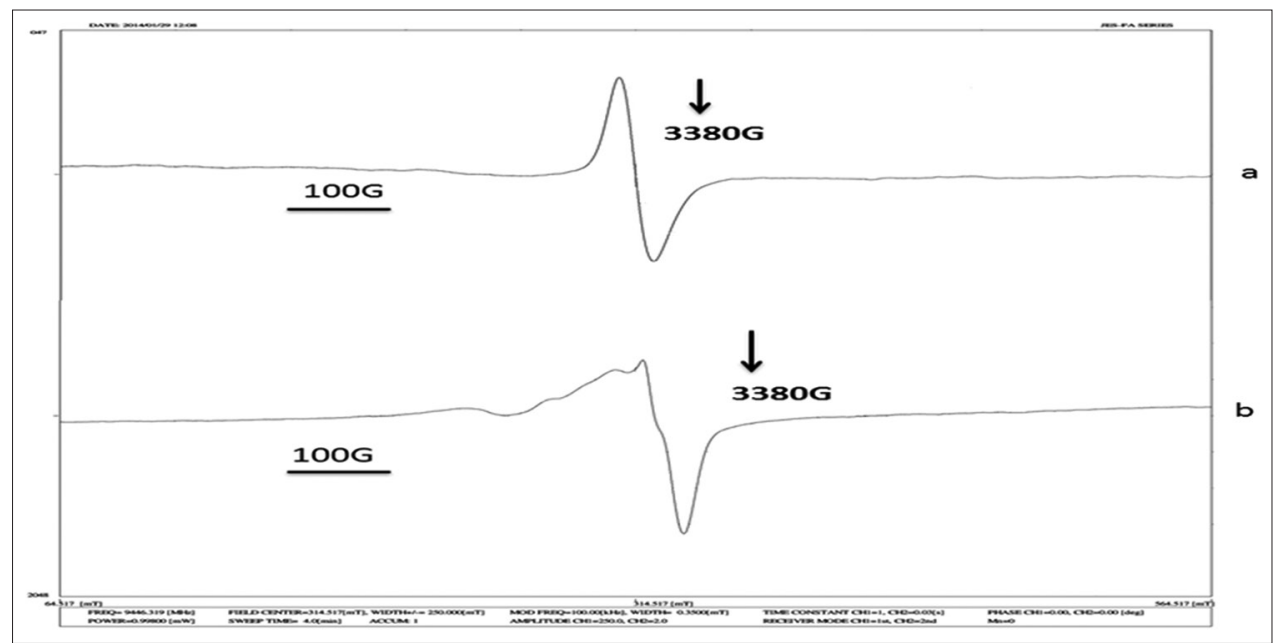

Fig. 1: Electron paramagnetic resonance spectra of $\mathrm{Cu}$ (4-amino antipyro-2-oxo-6-phenyl hexa hydro pyrimidine-5-carboxylate)2 complex in solid at (a) $300 \mathrm{~K}$, dimethyl sulfoxide (b) $300 \mathrm{~K}$, and (c) $77 \mathrm{~K}$

\section{ESR spectrum copper (II) complex}

The ESR spectrum of copper (II) complex has been studied and depicted in Fig. 1. The g\| and $\mathrm{g} \perp$ values have been found to be 2.04351 and 2.15835, respectively. The $g_{a v}$ was calculated to be 2.12007. The $\mathrm{Cu}$ (II) complex shows reversed axial (compressed octahedral) with $\mathrm{g} \|<\mathrm{g} \perp$. The trend $\mathrm{g} \|<\mathrm{g} \perp$ showed that the electron is delocalized in $\mathrm{dz}^{2}$ orbital of the ground state of $\mathrm{Cu}$ (II). In this case $(\mathrm{g} \|<\mathrm{g} \perp)$, distortion occurs by compression. The parameter G, determined as G $1 / 4$ (g\|- 2)/

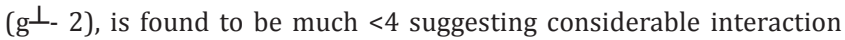
in the solid state. No band corresponding to $\mathrm{Ms}= \pm 2$ transition was observed in the spectrum ruling out any $\mathrm{Cu}-\mathrm{Cu}$ interaction. The g-tensor values of $\mathrm{Cu}$ (II) complex can be used to derive the ground state. In square-planar complexes the unpaired electrons lie in the $\mathrm{dx}^{2}-\mathrm{y}^{2}$ orbital giving $2 \mathrm{~B}_{1} \mathrm{~g}$ as the ground state with $\mathrm{g} \|>\mathrm{g} \perp$ while the unpaired electron lies in the $2 \mathrm{dz}$ orbital giving $2 \mathrm{~A}_{1} \mathrm{~g}$ as the ground state with $\mathrm{g} \perp>\mathrm{g} \|$. From the observed values, it is clear that $\mathrm{g} \|>\mathrm{g} \perp$, which indicate that the structure of the complex is square-planar and that the unpaired electron is predominantly in the $\mathrm{d} \mathrm{x}^{2}-\mathrm{y}^{2}$ orbital $[23,24]$. The molecular orbital coefficients, a2 (covalent in-plane s-bonding) and b2 (covalent in-plane p-bonding) were calculated using the following equations.

$$
\begin{aligned}
& \alpha^{2}=-(\mathrm{A} \| / 0 \times 036)+(\mathrm{g} \|-2 \times 0023)+3 / 7(\mathrm{~g} \perp-2 \times 0023)+0 \times 04, \\
& \beta^{2}=(\mathrm{g} \|-2 \times 0023) \mathrm{E} /-8 \lambda \alpha^{2},
\end{aligned}
$$

Docking studies of ligand and their metal complex

In the present study, in silico molecular docking studies of ligand and their metal complex against BCL-2(PDB id: Bcl-xl: 2YXJ) have been carried out using Glide module of Schrodinger. The docking studies which are reported in terms of the docking energy score, which means the lower, the score, the better, and the interaction. In the ligand, $[\mathrm{Zn}(\mathrm{APDM}) 2] \mathrm{Cl}_{2}$ and $[\mathrm{Cu}(\mathrm{APDM}) 2] \mathrm{Cl}_{2}$ were individually docked with (Laryngeal carcinoma) BCL-2 as the target protein. Docking results of a best complex of these compounds with their key active site residues interaction are tabulated in Table 4. From the table, these compounds exhibit better docking scores $(-7.92$ and $-6.52)$ and glide energies ( -58.60 and-53.25), respectively. Based on the docking score, the glide energy, and key active site interactions, the metal complexes show better binding affinity compared to ligand inhibitor. Molecular docking studies show that these metal complexes bind well in the active site pocket of BCL-2 (PDB id: Bcl-xl: 2YXJ) and interacts with the active site amino acid residues. In ligand, nitrogen atoms N1 interact with Glu 129(A) at distance of $2.90 \AA$ and also $\mathrm{O}_{2}$ interact with $\operatorname{Arg} 139(\mathrm{~A})$ at a distance of $2.73 \AA$ which is shown in Fig. 2. Docking score -7.92 of Tetrahedral [Zn (APDM) $)_{2} \mathrm{Cl}_{2}$, Oxygen atom $\mathrm{O}_{3}$ interacts with of Try195 (A) at a distance of $2.11 \AA$, Asn136 (A) at a distance $3.28 \AA$, and $05 \operatorname{Arg} 136(\mathrm{~A})$ at a distance $3.11 \AA$. . The compound $\mathrm{CuL}_{2}$ has a better binding interaction with Bcl-xl: 2YXJ protein and it exhibited the docking score -6.52 with a $-53.25 \mathrm{kcal} /$ mol. The hydroxyl group of the amino acid Tyr 101(A) made hydrogen bond interaction with the 06 of compound $\mathrm{CuL}_{2}(\mathrm{O} 6---\mathrm{OH})(\mathrm{Try} 101)$, 
Table 4: Induced fit docking results of all derivatives with LTA4H along with intermolecular hydrogen bond interactions with active site residues

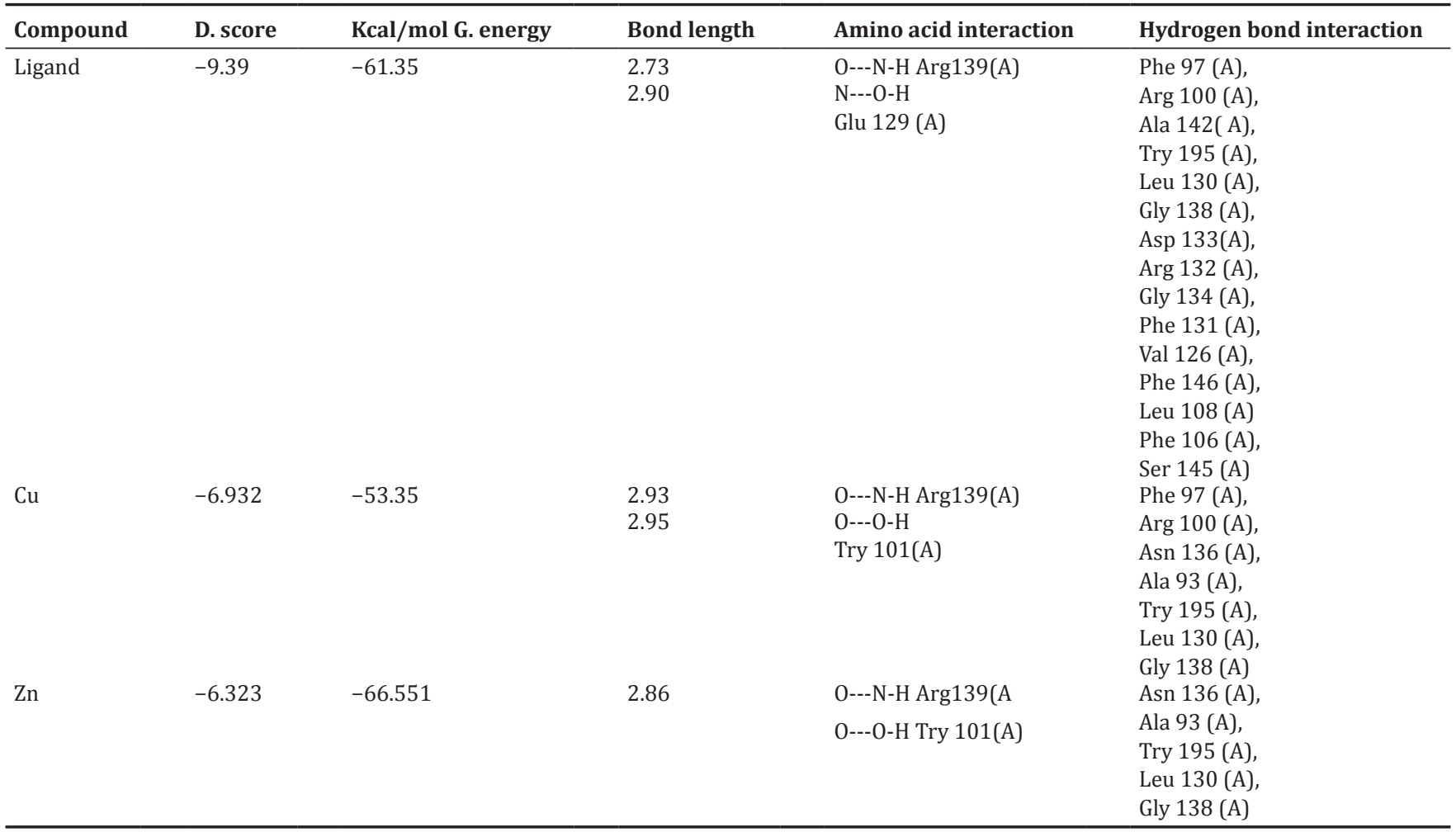

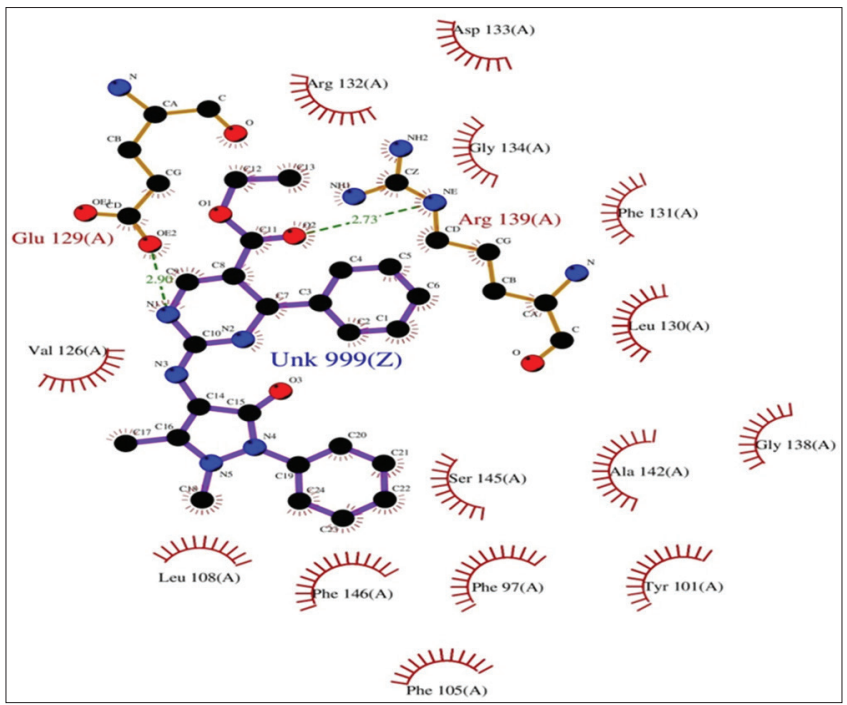

Fig. 2: Docking studies of the ligand of 4-amino antipyro-2-oxo-6phenyl hexa hydro pyrimidine-5-carboxylate

and bonding distance is $2.95 \AA$ A. Similarly, carbonyl group involves hydrogen bond interaction with $\operatorname{Arg} 139$ (A), and bond distance is $2.93 \AA$ A (Fig. 3).

\section{CONCLUSION}

A new bidentate complex was synthesized by a condensation reaction with transition metal (II) complexes and pyrimidine-based ligand. To evaluate biological modal with the BCL-2 molecular docking model suggested that compound $\mathrm{Cu}$ (II) and Zn (II) complexes act as potent BCL-2amino acid residues inhibitor as well as in vitro anticancer agent. Overall, the compounds have designed from the parent ligand APDM

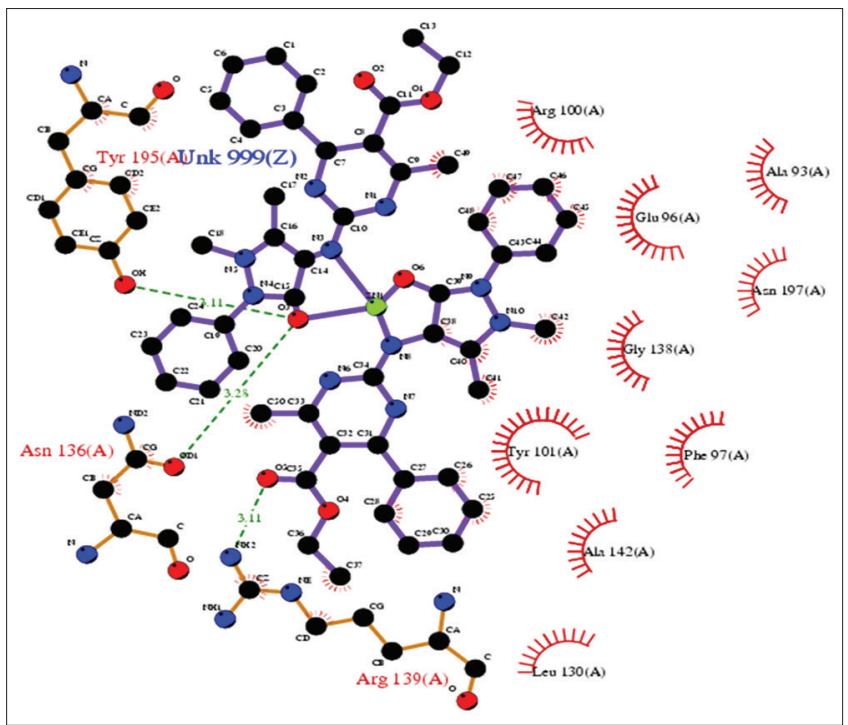

Fig. 3: Docking studies of Cu (4-amino antipyro-2-oxo-6-phenyl hexa hydro pyrimidine-5-carboxylat)2 complex

with Zn (APDM) showed potent activity in most of the studies. The present research could be useful to develop the in vivo studies of the synthesized compounds.

\section{AUTHOR'S CONTRIBUTIONS}

Corresponding author has done all the work, interpreted the data, and written the manuscript.

\section{CONFLICTS OF INTEREST}

All authors have none to declare. 


\section{REFERENCES}

1. Alexander V. Design and synthesis of macrocyclic ligands and their complexes of lanthanides and actinides. Chem Rev 1995;95:273-342.

2. Rosu T, Pasculescu S, Lazar V, Chifiriuc C, Cernat R. Copper(II) complexes with ligands derived from 4-amino-2,3-dimethyl-1-phenyl3-pyrazolin-5-one: Synthesis and biological activity. Molecules 2006;11:904-14.

3. Hitoshi T, Tamao N, Hideyuki A, Manabu F, Takayuki M. Preparation and characterization of novel cyclic tetra nuclear manganese (III) complexes: $\mathrm{Mn}^{\mathrm{III}}{ }_{4}(\mathrm{X} \text {-salmphen })_{6}\left(\mathrm{X}\right.$-salmphen $\mathrm{H}_{2}=\mathrm{N}, \mathrm{N}^{\prime}$-di-substitutedsalicylidene-1,3-diaminobenzene $) \quad(\mathrm{X}=\mathrm{H}, \quad$ 5- $\mathrm{Br}) . \quad$ Polyhedron 1997; 16:3787-94.

4. Hossain ME, Alam MN, Begum J, Akbar AM, Nazimuddin M, Smith FE, et al.The preparation, characterization, crystal structure and biological activities of some copper(II) complexes of the 2-benzoylpyridine schiff bases of S-methyl- and S-benzyldithiocarbazate. Inorg Chim Acta 1996;249:207-13.

5. Chiaramonte D, Steiner JM, Broussard JD, Baer K, Gumminger S, Moeller EM, et al. Use of a 13C-aminopyrine blood test: First clinical impressions. Can J Vet Res 2003;67:183-8.

6. Gudasi KB, Patil SA, Bakale RP, Nethaji M. Ligational behaviour of (E)-2-amino-N'-[1-(2-hydroxyphenyl) ethylidene] benzohydrazide towards later $3 \mathrm{~d}$ metal ions: X-ray crystal structure of nickel (IV) complex. J Mol Struct 2014;1065:179-85.

7. Kandeel ZE, Abdelrazek FM, Eldin NE, Elnagdi MH. Activated nitriles in heterocyclic synthesis-novel synthesis of benzo[g]imidazo [1,2-c] pyrimidines and benzo[g]imidazo [1,2-a]pyridine derivatives. J Chem Soc Perkin Trans 1985;1499-501.

8. Manjula J, Maheswari R. Biological and studies of novel aroyl hydrazones. Int J Pharm Pharm Sci 2017;9:81-5.

9. Sekar S, Naik N, Mahalingappa SA, Peethamber SK. Synthesis and pharmacological evaluation of certain schiff bases of octahydro1H-pyrrolo [3, 4-b] pyridine derivatives. Int $\mathrm{J}$ Pharm Pharm Sci 2015;9:412-9.

10. Kowol CR, Berger R, Eichinger R, Roller A, Jakupec MA, Schmidt PP, et al. Gallium(III) and iron(III) complexes of alpha-N-heterocyclic thiosemicarbazones: Synthesis, characterization, cytotoxicity, and interaction with ribonucleotide reductase. J Med Chem 2007;50:1254-65.

11. Chitambar CR. Gallium nitrate for the treatment of non-hodgkin's lymphoma. Expert Opin Investig Drugs 2004;13:531-41.

12. Fanagdi MH, Kandeel EM, Zayed EM, Kandil ZF. A novel synthesis of 3, 5-diacetamidopyrazole and of 2-aminopyrazolo [1,5-a] pyrimidines. J Heterocycl Chem 1977;14:155-7.

13. Raman N, Sakthivel A, Rajasekaran K. Synthesis and spectral characterization of antifungal sensitive schiff base transition metal complexes. Mycobiology 2007;35:150-3.

14. Leelavathy C, Antony SA. Structural elucidation and thermal studies of some novel mixed ligand Schiff base metal (II) complexes. Int J Basic Appl Chem Sci 2013;3:88-95.

15. Elemike EE, Oviawe AP, Otuokere IE. Potentiation of the antimicrobial activity of 4-Benzylimino-2, 3- Dimethyl-1-Phenyl-pyrazal-5-One by metal chelation. Res J Chem Sci 2011;1:6-11.

16. Prakash D, Kumar C, Prakash S, Gupta AK, Singh KR. Synthesis, spectral characterization and antimicrobial studies of some new binuclear complexes of $\mathrm{Cu}$ II and Ni II Schiff base. J Indian Chem Soc 2009;86:1257-61.

17. Huheey JE, Keiter EA, Keiter RL. Inorganic Chemistry. $4^{\text {th }}$ ed. India: Addison-Wesley Publishing Company; 1993.

18. Drago RS. Physical Methods in Inorganic Chemistry. New York: Reinhold Publishing Corporation; 1965.

19. Dutta RL, Syamal A. Elements of Magnetochemistry. $2^{\text {th }}$ ed. New Delhi: East-West Press; 1993.

20. Akkasali R, Patil N, Angadi SD. Synthesis, characterization and microbial activities of metal complexes with. Coumarine derivatives. Rasayan J Chem 2009;2:81-6.

21. Raman N, Muthuraj V, Ravichandran S, Kulandaisamy A. Synthesis, characterization and electrochemical behaviour of. $\mathrm{Cu}$ (II), $\mathrm{Co}$ (II), $\mathrm{Ni}$ (II) and $\mathrm{Zn}$ (II) complexes derived from acetyl acetone and p-anisidine and their antimicrobial activity. Proc Indian Acad Sci (Chem Sci) 2003;115:161-7.

22. Malik WU, Tuli GD, Madan RD. Selected Topics in Inorganic Chemistry. $1^{\text {st }}$ ed New Delhi: S. Chand and Company Ltd.; 1976, 2004. p. 390 .

23. Annapoorani S. Synthesis and spectroscopic characterization of some copper (ii) trinuclear complexes involving nitrogen as bridging atoms. Asian J Chem 2012;24:3347-51

24. Chandra S, Sangeetika X. EPR, magnetic and spectral studies of copper(II) and nickel(II) complexes of schiff base macrocyclic ligand derived from thiosemicarbazide and glyoxal. Spectrochim Acta A 2004;60:147. 